Choices and policies

\title{
Escolhas e políticas
}

Jeni Vaitsman ${ }^{3}$

As a co-editor in this supplement, together with Nilson do Rosário Costa, I could not refrain from making a few comments on his deep and provok- 
ing analysis of the relationships between institutional rules, macroeconomic constraints and innovations in the Brazilian social protection system after the 1988 Constitution. The issues addressed are diverse and of distinct natures.

The text criticizes el oquently the linear association between macroeconomic adjustment and social policy, highlighting therole of internal processes regarding external constraints. It emphasizes the institutional conditions favorable to building a social protection system, in spite of the macroeconomic adjustment agenda, even though that same agenda did determine the emphasis given to targeting the protection of the poor, above all through the Bolsa Família Program (Family Grant Program). The development of the social policy would have gained relative autonomy in relation to the economic policy, the priority now being theissue of fighting poverty, misery and social inequities.

While the FHC administration, although adhering to the targeting agenda, would have expanded the federative decentralization in health and education, in a process which "was closely related to the democratization and criticism to the authoritarian centralization of the military regime and not with the State reform agenda of the 1990's", the Lula administration would have made other choices. The creation of the Bolsa Família Program directly affected the availability of resources of the central government for basic social areas - health, education, and sanitation.

The author highlights the conflicts and choices - tragic, in the Brazilian inequity scenario - between policies. However, what is considered as an advance in the education and health areas in the 1990's, "the expansion of the federative decentralization in health and education", in my view, is similar to the process which the social assistancewent through in theyears 2000, above all after 2004. The national expansion of the Bolsa Família Program and its converging with the Unified Social Assistance System expanded the federative decentralization to the social assistance sphere, a component of the social security which was neglected up until then. In the sphere of assistential rights, the main assistential right to income transfer, which did not depend on contributions and guaranteed by the Constitution, the Continuous Cash Benefit, for elderly and disabled persons, which started to beimplemented in 1996 with an average of 346,000 beneficiaries, reached a cover of 2.68 beneficiaries in $2007^{1}$.

On the other hand, the social development agenda after 2004 did not cause a rupture with the tradition of the movement of fight against hunger and food security, which guided the social agenda in the first year of office, but in redirecting it. The fight against hunger and food insecurities was now treated as part of an integrated vision of social development. It was not a coincidence that the Extraordinary Ministry for Food Security and the Fight Against $\mathrm{H}$ unger (MESA), the M inistry for Social Assistance and the Executive Secretariat for the Bolsa Família Program merged with the new M inistry of Social Development and the Fight Against Hunger, being granted the status of national secretariats (National Secretariat for Food and Nutrition Security, National Secretariat for Social Assistance and National Secretariat for Citizenship Income) with equivalent hierarchic levels. There was no rupture, but an institutionalization, a transformation of political agenda into public policy. The Consea, which had been dissolved in the FHC administration and re-established in the Lula administration, had a central role in passing the Organic Act of Food and Nutrition Security in 2006 and in founding the N ational System on Food and N utrition Security (SISAN $)^{2}$.

The unification of the income transfer programs and the areas of food security, incometransfer and social assistance managed by the MDS meant, with the converging policies and actions, a new guidance to face the issue, also highlighted by the author, of "a relevant and diffuse set of assistance benefits" and the redundancy of programs and double beneficiaries.

Regarding the numbers for the year 2003 presented in TablellI, I disagreethat the unification of incometransfer programs in the Bolsa Família Program would haveproduced a reduction of 4,722,031 beneficiaries in incometransfer programs between 2003 and 2006. The total number of families benefitted in the year 2003 (16,335,596 families) has been distorted, since it expresses double families. When the Bolsa Família Program was created in October 2003, several registries coexisted and juxtaposed and one single family could be in several different registries. The unification of programs also meant the registry unification, the Unified Registry System for Federal Government Social Programs, which was gradually - and with countless operational difficulties - filtering the inconsistencies and repetitions and incorporating in the same data base the beneficiaries of programs prior to the Bolsa Família Program.

Between $O$ ctober and December 2003, thenumber of beneficiaries of the Bolsa Família Program represented basically the beneficiaries which migrated from previous programs. From 2004, in parallel with the ongoing migration process, there was an increase in the inclusion of families who 
were not until then beneficiaries of any federal income transfer program. From 2003, as the number of beneficiaries and the amount granted by the Bolsa Família Program increased, the transfer and number of beneficiaries of the remaining programs decreased. When it comesto the program's national expansion, between October 2003 and October 2004, the municipalities covered rosefrom 4,396 to 5,521 , reaching the total number of municipalities in $2006^{3}$.

In addition to the issue of quantity, there is an issue of quality, or of meaning. The Gas Voucher expanded the reach of the social programs, for although it covered 8 million families, the ben efits were limited to $R \$ 15,00$ every 2 months. The unification of the programs increased the average amount of the income transfer grants, from $\mathrm{R} \$$ 23,24 to $R \$ 68,13$ in October 2004 values $^{3}$.

The comparison of the budget and spending on different sectors is crucial to understand the political priorities in relation to the public policies. But as the text itself points out, other variables must betaken into account in order to explain why certain choices are made or why certain sectoral policies are more successful in its institutionalization and results than others. This was not theintent of the article under discussion, but it is one of the issues it raises. The sectoral processes of institutionalization of policies are not symmetric or regular. In two decades of democratization, reforms and innovation, the decentralization of social policies has been taking place in distinct paces and producing different sectoral configurations.

This debate poses the problem of explanation, of finding vocabulary, creating theories for what is new and upcoming in the confluence of different processes, internal and external, but acquires its own meaning in specific contexts. In terms of an agenda on policies research in a compared perspective, two issues arise: on theonehand, theneed to understand the nature, the processes and the sectoral logic involving the mobilization of different actors and interests which influence the formulation and implementation of social protection policies in specific contexts. On the other hand, understanding that the social protection system is under construction, seeing it in the inequity and exclusion contexts that it attempts to overcome through its set of policies, whether they areuniversal or targeted.

\section{References}

1. Brasil. Ministério do Desenvolvimento Social e Combate à Fome. [acessado 2009 jan 30]. Disponível em: http://aplicações.mds.gov.br/sagi/miv/miv.php

2. Burlandy L. A construção da política de Segurança Alimentar e Nutricional no Brasil: estratégias e desafios para a promoção da intersetorialidade no âmbito federal de governo. Cien Saude Colet 2009; 14(3):851-860.

3. Brasil. Ministério do Desenvolvimento Social e Combate à Fome. Dados dos Programas do M inistério do Desenvolvimento Social e Combate à Fome, 2004. [acessado 2009 jan 30]. Disponível em: http:// www.mds.gov.br 